J O U R N A O F French and Francophone Philosophy
RE V UE DE LA

philosophie française et de langue française

\title{
How to Live?
}

\section{One Question and Six or Seven Life Lessons with Albert Memmi}

\section{Debra Kelly}

Journal of French and Francophone Philosophy - Revue de la philosophie française et de langue française, Vol XIX, No 2 (2011) pp 67-95

\author{
Vol XIX, No 2 (2011) \\ ISSN 1936-6280 (print) \\ ISSN 2155-1162 (online) \\ DOI $10.5195 /$ jffp. 2011.472 \\ www.jffp.org
}

\section{(cc) EY-NC-ND}

This work is licensed under a Creative Commons Attribution-Noncommercial-No Derivative Works 3.0 United States License.

\section{ULIS D-Sunt}

This journal is operated by the University Library System of the University of Pittsburgh as part of its D-Scribe Digital Publishing Program, and is co-sponsored by the University of Pittsburgh Press 


\title{
How to Live?
}

\section{One Question and Six or Seven Life Lessons with Albert Memmi}

\author{
Debra Kelly \\ University of Westminster
}

\begin{abstract}
Il s'agit en somme d'une longue entreprise, d'un seul livre constitué par un emboîtement de livres l'un dans l'autre. J'aime cette façon de mettre une cuvre dans une autre et une troisième dans une seconde. Ce n'est pas là un artifice, je crois au contraire que c'est l'expression même de la réalité qui va se creusant, se découvrant de plus en plus profonde.
\end{abstract}

(It's a long enterprise, it's one single book made up of a linked series of books, one inside the other. I like that way of putting one work inside another and a third inside the second. It isn't an artifice but just the reverse: I think it's the very expression of reality entering more and more deeply into itself, progressively revealing its own depth.)

\section{Albert Memmi, Le Nomade immobile ${ }^{1}$}

\section{A Life of Writing: "Stages on the Same Journey"2}

It is perhaps obvious to begin by saying that the work of Albert Memmi is wide-ranging both in breadth and in time, covering more than half a century of literary works, socio-political studies and essays of various types - whether academic or for the wider public. In addition to his creative work beginning in 1953 with La Statue de sel (The Pillar of Salt) and continuing to 1988 with Le Pharaon (The Pharaoh) and the later collection of short stories Téresa et autres femmes (Teresa and Other Women) in 2004, he has made, in a series of important studies on various types of oppression and dominance, original contributions to political, sociological and psychological thinking with concepts such as the "duo" and "la dépendance" (dependence), and his definition of racism adopted by the Encyclopaedia Universalis. ${ }^{3}$ It is therefore 
important to understand what this long career as a writer and a thinker means and how both the author himself and his readers may assess it. Memmi's work is, in every sense, a "life project": a coherent project pursued throughout his long life as an intellectual, but also as the member of a minority group, as he has consistently reminded his readers. It is therefore a personal project that is intimately intertwined with the life experiences of an individual, yet has implications for understanding broader communities and societies. ${ }^{4}$ The implication - and sometimes explicitly stated intention - is that this is a life project from which the individual concerned and others who read the work can learn something, at both private and public levels, concerning the functioning of human interactions. The work from 2000 onwards with the publication of Le Nomade immobile (The Stationary Nomad), then, for example, the Dictionnaire critique à l'usage des incrédules (Critical Dictionary for the Use of Non-believers) in 2002 and Testament insolent (Insolent Testament) in 2009 represents Memmi in his eighties explicitly "taking stock" of his life, his career, his writing, his various contributions to sociology and politics. This "taking stock" increasingly takes what can be termed in the broadest sense a philosophical turn, to be understood in both the more popular and academic senses. These recent texts revisit a number of issues and themes from previous works, sometimes in a very similar format and form of expression. There is a certain sense of repetitiveness and, as one critic has noted, one aim of this seems undoubtedly to be: "la garantie et la prolongation de l'écriture et de sa publication" (to guarantee and to prolong his writing and its publication). Memmi writes retrospectively in order to "accéder à un ordre analytique" (reach an analytical position) and this "selfmastery" leads to "la sagesse présente dans les derniers textes, dont la fragmentation est révélatrice d'un soin de détachement et de l'apaisement longtemps poursuivi" (the wisdom present in the later texts, whose fragmentary style reveals the care taken to achieve the detachment and calm which he has pursued for a long time). ${ }^{5}$ Is this the wisdom of old age? The consciousness of ageing is already very explicit in the prologue and epilogue to Le Nomade immobile and reappears in the first chapter of his Testament insolent, linking the two texts with a similar aim although almost a decade separates them. What is strikingly absent in these texts of late life, however, is any sustained meditation on old age, on the process and meaning of ageing and on death itself. Memmi's way of writing and of ensuring continuing publication and new audiences may be seen as an implicit acknowledgement of ageing, but the themes and concepts tackled are rather familiar to previous readers of Memmi's work. This is all the more surprising given Memmi's implicit and explicit references to Montaigne (to whom I shall return) and the original essayist's own discussion of the meaning of old age. It may be that Memmi is unconsciously working within the framework of Erikson's socially conservative and "positive ageing" work that rids the experience of growing older: "[...] of ambivalence and ambiguity. Rather than a brute process of disengagement and decline, 
ageing becomes a meaningful progression through a hierarchy of stages, each closer to perfection than the last" ${ }^{6}$ In Erikson's generational scheme, the "ego goal" for old age is integrity, the positive attribute which combats despair. ${ }^{7}$ Since ageing is an inescapable element of the human condition, it could have captured Memmi's attention, particularly given the injustices and forms of oppression that contemporary societies visit on their own ageing populations. However, he chooses rather the notion of an inventory to review and revisit the ideas of a lifetime, writing in 2000:

Dirais-je que toute mon œuvre jusqu'ici aura été un même effort d'inventaire, tantôt grâce à la fiction, tantôt grâce au portrait, à l'essai, ou même à la recherche la plus technique qui me permet la vérification précise, la formulation mathématique de tel ou tel point de cet itinéraire: voilà le sens et la place de tel travail sociologique sur le racisme, d'une étude psychanalytique, ou d'une investigation sur la connaissance d'autrui. ${ }^{8}$

(I might say that all my work up to the present has been part of the same effort to take stock, sometimes through fiction, sometimes through a portrait or an essay, or even through the most technical kind of research which enables me to make a precise verification, a mathematical formulation of this or that point on the itinerary. That's the meaning and the place of a given social study of racism, or psycho-analytical study, or research into the knowledge of others.)

What then, does such an inventory of a lifetime of writing mean?

\section{Memmi and Philosophy: "bien penser pour bien agir"9}

C'est en racontant mon échec philosophique que je suis devenu écrivain. Je suis un éclopé de la philosophie, et sans doute l'écriture m'a-t-elle littéralement sauvé.

(It was while describing my failure as a philosopher that I became a writer. I am a casualty of philosophy, and, unquestionably, writing literally saved my life.)

\section{Albert Memmi, Le Nomade immobile ${ }^{10}$}

For all his professed failure with regard to philosophy as a young man, and his rejection of his initial wish to be a philosopher, Memmi constantly alludes in these later texts to a philosophical impulse in his work. In the introduction to the Dictionnaire critique, he notes that: "Ce dictionnaire est aussi, d'une certaine manière, mon journal et celui de notre temps. Mais on y verra également, je l'espère, l'esquisse d'une philosophie" (This dictionary is also, in a way, my diary and a diary of our time. But there will also be found 
in it, I hope, the sketch of a philosophy). ${ }^{11}$ Like Montaigne, frequently referred to in his writing, Memmi constructs his dictionary: "afin de m'épargner mes propres errements, complaisances et complicités" (to spare myself my own wanderings, complacencies and complicities). ${ }^{12}$ Focusing then primarily on some of Memmi's later publications from 2000 onwards, in which he is clearly aiming to construct some sort of "bilan" (an evaluation, an assessment) of his life and work, this articles takes as its premise the notion that both the author and his reader may take a series of "life lessons" from the "conclusions" (however provisional) at which he arrives. Although a similar observation to this - that the meditation on individual experience finds multiple and diverse forms of expression and opens up the potential for the understanding of a more universal experience - can be said of other writers, it is particularly true for Memmi's project. ${ }^{13}$ Memmi began this project by making clear the universal dimension of his own experience and that of the Jews of Tunisia in the first part of the twentieth century, showing how a particular situation of oppression may reveal the dynamics underlying all systems of subjugation. Of his political and sociological studies Portrait du colonisé, précédé de Portrait du colonisateur (The Colonizer and the Colonized) remains a seminal text for Postcolonial Studies, and his work on Jewish identity and on racism, for example, places him among the most important thinkers in these domains as well. It is in his first key theoretical text that Memmi presents his concept of the "duo" (here colonizer and colonized), which is later applied to the duos of white/black; man/woman; Jew/non-Jew, etc. He shows the two members of the "duo" to be inextricably linked as he uncovers the working of the power relationships between them, and indeed he has been referred to as "le philosophe des duos." ${ }^{14}$ Reviewing this concept in Testament insolent, Memmi defines it succinctly - the definition of ideas and concepts increasingly becoming a kind of culmination of his thinking - "le duo n'est pas une simple rencontre, accidentelle et sans conséquences, entre deux partenaires ou deux adversaires: ils en sont tous les deux transformés" (the duo is not a simple encounter, accidental and without consequences, between two partners or two adversaries: both of them are transformed by it) ${ }^{15}$. His work on colonization is his best-known, and has tended to overshadow his thinking in other areas and disciplines, notably on the notion of "dependence", to which he has made no less important contributions. His work on dependence can be considered a development of his analysis of the functioning of dominance at work in human relationships and behavior, although there are important differences in dominance and dependence. The latter rests on need and therefore pleasure, according to Memmi, and while dominance is unstable, dependence is a force of stability. The notion of dominance and its functioning preoccupied Memmi's thinking for many years, but he emphasizes his fascination with the discovery of dependence as fundamental to the human condition:

En tout cas, j'ai tendance à penser que la dépendance est à la racine de notre condition d'humaine. Elle n'est pas un 
vice comme l'affirment certains moralistes, ni une maladie comme veulent le croire certains médecins; elle nous constitue depuis notre naissance et nous accompagne le long de notre existence. ${ }^{16}$

(Anyway, I tend to think that dependence lies at the root of our human condition. It is not a vice, as some moralists claim, nor a sickness, as some doctors would like to believe; it is what constitutes us from the moment of our birth and accompanies us throughout our lives.)

Notably, his definition links it to desire: "la dépendance est une relation contraignante avec un être, un objet, un groupe ou une institution, réels ou idéels, et qui relève de la satisfaction d'un besoin ou d'un désir" (dependence is a constraining relation to a person, an object, a group or an institution, whether real or ideal, and is very like the satisfaction of a need or a desire). ${ }^{17}$ Indeed, dependence becomes integral to his philosophical thinking "si la philosophie a surtout comme but la compréhension de l'être humain," (if philosophy has as its foremost goal the understanding of the human being), and it is the basis of a philosophy of alterity, and of social relations. ${ }^{18}$. Among his other seminal concepts, Memmi has also devoted studies to the relations between men and women (since the fundamental "duo" in society is that of the couple) which entail, in his analysis, both dominance and dependence. His work as a whole can indeed be summed up as a "philosophy of human relationships,"19 studying as it does all forms of domination, oppression, and (inter)dependence. Memmi has himself frequently explained the ways in which his thinking developed from the individual case to the universal dimension, and how the two are interlinked. He uncovers the mechanisms at work in the power balance of human relationships on both micro- and macro-levels, moving, for example, from the dynamics of the relationship in a Tunisian-French marriage, the relationship between colonizer and colonized, to the relationship between the Jew and the rest of the world: " Du même coup, je venais d'entrevoir un phénomène infiniement plus vaste, plus térrifiant: la relation de la dominance qui ordonne les rapports de tant d'êtres humains" (At the same time I had just glimpsed an infinitely more vast and more terrifying phenomenon: the relationship of dominance which governs the mutual dealings between so many human beings) ${ }^{20}$ At the same time, he has no illusions concerning the limits of the passage from the individual to the universal in its practical application and does not hold back on the analysis of his own position and motivations:

En tant qu'un homme moral aspirant à l'universel, le sort de tous les hommes devrait m'être également préoccupant. Mais je ne suis pas un homme universel, je suis d'abord un homme singulier, avec des attaches particulières. Mes liens avec les autres hommes se diluent à mesure que m'en éloignent la culture et la géographie. 
La fameuse déclaration de Montesquieu sur la préférence qu'il accorde au général sur le singulier, à l'humain sur le familial, est mal interprété, me semble-t-il: ce n'est pas un constat, c'est un souhait éthique, une décision juridique. ${ }^{21}$

(As a moral being aspiring to the universal, the fate of all humans should concern me equally. But I'm not a universal man; I am firstly an individual, with particular attachments. The further I am from other men culturally or geographically, the weaker my links with them grow. Montesquieu's famous declaration about the preference he accords to the general over the individual, the whole of mankind over his own family, is, I think, misinterpreted: it is not an observed fact but an ethical aspiration, a juridical decision.)

Among other constantly re-worked problematics in Memmi's work are the question of the liberation of the collective and the individual in the face of all forms of oppression, the ensuing search for identity and, bound up inextricably and essentially with this, the quest for a "truth" about human existence and for a set of values, for a way of being in the world. Memmi has also talked about all the facets of his work as being interconnected and of how his life is itself further interconnected with his published work:

Chacun de mes livres aura été une étape d'un même itinéraire. J'aurais passé la majeure partie de ma vie à écrire. L'écriture m'a souvent servi de béquille; chacun a la sienne, de sorte que ma vie et mon travail se répondent ; de sorte que parlant de l'une je parle de l'autre, et inversement [...] J'ai sans doute plus fortement besoin de m'expliquer, de plaider peut-être. ${ }^{22}$

(Each of my books will have been a stage on the same journey. I will have spent the greater part of my life writing. Writing has often served me as a crutch; everyone has their own, so that my life and my work correspond to each other, and in speaking of one I am speaking of the other, and vice versa. [...] Unquestionably, I have a stronger need to explain myself, to plead, perhaps.)

What then is the reader to make of this "pleading"? In Le Nomade immobile, Memmi is very clear about his disappointment with the philosophy professors at the Sorbonne (at which he studied after the Second World War, following his earlier studies in the subject at the University of Algiers) and the impact on his initial enthusiasm for philosophy that had begun with his admiration for his teacher at the French lycée in Tunis. Yet in his writings of old age, the writer and sociologist again turns increasingly into a philosopher as he surveys his life, explains and justifies his work, and makes 
clear his version of certain events in his life. Memmi, the perhaps reluctant philosopher, pursues a set of values by which to live, and although far from constituting a philosophical "system" or treatise, these represent an articulation of how to conduct oneself within human society, and of how to analyze that society in order to live as well as one can without falling dupe to the various "illusions" that beset rational thought. Describing Testament insolent he tells us that he finds the term "philosophical" difficult and that it does not quite describe his aim:

En somme, il s'agit à la fois d'un plaidoyer et d'un testament philosophique? C'est également vrai, même si je ne tiens pas tellement à l'adjectif philosophique, trop chargé et rebutant pour beaucoup. Mettons plutôt une tentative d'autobiographie, philosophie inclusive. Leçons d'une vie, plus modeste, m'aurait peut-être convenu davantage. ${ }^{23}$

(All in all, is it at once a plea and a philosophical testament? That is equally true, even if I don't really like the word philosophical, a somewhat loaded term that many find off-putting. Let's say, rather, an attempted autobiography, with philosophy included. The more modest lessons of a life would perhaps have suited me better.)

If we follow Memmi's method, then we can move from the individual "lessons of a life" to the more universal "life lessons". For all his hesitation around the term "philosophy", his commitment to the role of the intellectual writer is clear. For Memmi, the writer is necessary to his society and he maintains an ethical position on writing as for other social behavior: a writer's work should be a kind of testimony to a way of living, and as I have previously suggested, a way of being in the world. From the publication of Portrait $d u$ colonisé onwards, Memmi became, as he says (using Sartrean terminology), "un écrivain engagé" (a committed writer), and this commitment affects the status of his work. ${ }^{24}$ Once again describing writing as a "plea", Memmi powerfully underscores the ethical dimensions of its implications for both writer and reader (by slightly misquoting Baudelaire in the infamous first poem of Les Fleurs du mal, notably omitting the word "hypocrite" before Baudelaire's own address to the reader):

Ma littérature, sinon toute littérature, est un aveu et un plaidoyer. Un aveu donc un plaidoyer: je ne suis pas méchant puisque j'avoue, puisque je sollicite la compréhension du lecteur et la rémission [...] C'est le soulagement de la confession, confession réciproque où l'auteur, se confessant, confesse son lecteur - "Lecteur, mon semblable, mon frère!" 25 
(My literature, if not all literature, is a confession and a plea. A confession and therefore a plea: I'm not playing a trick, because I confess, because I beg for the understanding of the reader and for remission [...]. It is the solace of confession, reciprocal confession in which the author, by confessing, hears the confession of the reader 'Reader, my likeness, my brother!')

It is this recognition of the self of the writer laid out before the reader, and in whom the reader recognizes himself, that again brings to mind another writer and perhaps reluctant philosopher frequently mentioned by Memmi - Montaigne. The remainder of this article is constructed with an acknowledgement to the award-winning biography in which Sarah Bakewell recently brought a new life of Montaigne to the attention of the English-speaking world, her How to Live: A Life of Montaigne in one question and twenty attempts at an answer. ${ }^{26}$ Montaigne's essays, as Blakewell says, rarely explain or teach anything, but:

He used his experience as the basis for asking himself questions, above all the big question that fascinated him as it did many of his contemporaries. Although it is not quite grammatical in English, it can be phrased in three simple words: 'How to live'. This is not quite the same as the ethical question: 'How should one live?' [...] He wanted to know how to live a good life - meaning a correct or honorable life, but also a fully human, satisfying, flourishing one. ${ }^{27}$

This chimes well with the epilogue to Nomade immobile, as will be seen in the concluding remarks here.

A fitting analogy may therefore be made with the position of Montaigne, who, for all his sense of self-knowledge and self-acceptance later in life, retains a fluidity and a relativism with regard to the self that make his notion of identity appear "modern" to contemporary readers, and who is credited in intellectual and literary histories with inventing the essay form, a form much used by Memmi in many and varied ways. Montaigne "practises wisdom" in writing, and has a way of talking about the self that is not introverted, but results rather in more attentive observation of the outside world. It is the experience of the everyday and of the small realities of human existence, as well as the "large truths", which are indispensable to both Montaigne and Memmi. Memmi tells us that Montaigne sometimes tries his patience, but like so many of Montaigne's readers, he also refers to him as a friend and sees something of himself in him. Among Memmi's favorite bedside books are, he tells us, "les moralistes, Montaigne surtout [...] qui est toujours de bonne compagnie (n'avons-nous pas presque la même vie, lui dans sa tourelle, moi dans mon grenier?)" (the moralists, 
especially Montaigne [...] who is always good company (haven't we led almost the same life, he in his tower and I in my attic?)) ${ }^{28}$. Memmi is often severe about his own conduct and that of others, in keeping with the moralist he felt he had to become since he refused religious faith: "je suis devenu, surtout, un moraliste: pour expliquer et légitimer ma conduite autrement que par un acte de foi" (I have become, above all, a moralist: to explain and legitimize my behavior otherwise than by an act of faith). ${ }^{29}$ The headings of many of the chapters in Le Nomade immobile serve to indicate the major stages in Memmi's life and thought: "La révolte ou le néant"; "Le prix du savoir"; "Le pont suspendu"; "L'apprentissage de la solitude"; "Retour au pays"; "Fécondités de l'exil"; "Les appartenances multiples"; "La dimension juive"; "Nous somme tous des dépendants"; "Le salut par l'écriture"; "La religion: une fiction commode"; "Il n'existe pas de société sans morale"; "La politique : attachement et détachement"; "La philosophie : bien penser pour bien agir" ('revolt or nothingness'; 'the price of knowledge'; 'the suspension bridge'; 'the apprenticeship of loneliness'; 'return to the native country'; 'fecundity of exile'; 'multiple belongings'; 'the Jewish dimension'; 'we are all dependents'; 'salvation through writing'; 'religion, a comfortable fiction'; 'there is no society without morality'; 'politics: attachment and detachment'; 'philosophy, thinking rightly in order to act rightly'). One of the striking aspects of Le Nomade immobile is the often pitiless analysis that Memmi exercises on himself and on others around him, and the reader begins to understand how the writer forged this individual moral stance mentioned above:

$\mathrm{Au}$ lycée, j'embarrassais mes professeurs par des questions à contre-courant; je continuais à l'université, contre les doctrines en vogue - le marxisme stalien et le catholicisme, qui prévalait alors à la Sorbonne. Plus tard contre l'existentialisme, un certain structualisme, puis le lacanisme qui leur disputa la place. Non que je fusse toujours sûr de moi, mais là encore la critique l'autocritique, bien sûr - était la règle pour mieux diriger ma pensée. Je me méfiais de tout ce qui, devenant une pensée collective, ne laisse pas de place à l'initiative individuelle [...] L'intellectuel a d'autant moins de droit de ruser avec la vérité qu'il est plus outillé pour la découvrir, et qu'on l'attend de lui. S'efforcer de voir clair et dire clairement est sa fonction, sinon à quoi sert-il ?

C'est durant mes années au lycée que je forgeai ma doctrine à cet égard. ${ }^{30}$

(In high school I embarrassed my teachers with questions which went against the current; I continued to do this at university, against the doctrines then in vogue: Marxist Stalinism and Catholicism, which were the prevailing 
trends at the Sorbonne. Later, against Existentialism, a certain Structuralism, and then the Lacanianism which aimed to replace them. Not that I was always sure of myself, but there too criticism - and self-criticism, of course - was my rule for the better guidance of my thinking. I mistrusted everything which, becoming a collective way of thinking, leaves no room for individual initiative [...]. The intellectual has the less right to play about with truth insofar as he is better equipped to discover it, and as people expect it from him. His function is to do his utmost to see clearly and speak clearly otherwise, what is he there for?

It was during my years in high school that I worked out my doctrine on all this.)

As previously noted, Memmi would have perhaps preferred, more modestly he tells us, to have called his "testament", "lessons of a life", one life then, his; but there are life lessons to be drawn not only for the individual concerned but also for others, and the quotation above makes explicit what Lesson One will be.

\section{One: Think For Yourself}

In Le Nomade immobile, Memmi fully acknowledges the importance of his education in his ensuing revolt against his background: "[...] le savoir! Je devais le recueillir patiemment, pieusement" (knowledge! I had to gather it patiently, devoutly) 31 , but the ensuing resentment and guilt towards his family is as terrible for the old man who writes Le Nomade immobile as it was for the young man who wrote La Statue de sel. In Le Nomade immobile, Memmi makes clear that he had to distance himself from his family and "judge them"; resentment finally turned to compassion, but the relationship became no easier:

Pour faire mon salut, il me fallait également prendre mes distances avec les miens, c'est-à-dire aussi les juger. Et lorsque le ressentiment se fut transformé en compassion, ce ne fut pas plus commode. Je ressentis la vrille de la culpabilité [...] Je le payerais cher. En me punissant [...] j'étais toujours occupé à comprendre, afin d'agir plus efficacement. De la pitié ou de la violence, je ne sais pas ce qui est le plus difficile à vivre. ${ }^{32}$

(To find my own salvation I also had to distance myself from my family, i.e. to judge them as well. And when my resentment had been transformed into compassion, it was no more comfortable. I felt pangs of guilt [...] I would pay dearly for this. By punishing myself [...] I was always busy understanding, so as to act more effectively. Pity and 
violence: I don't know which of the two is more difficult to live with.)

The role of any thinker is not to tell people what they want to hear, but what $\mathrm{s} /$ he believes is right and just. S/he must not be afraid to incite criticism, and must also be self-critical. ${ }^{33}$ The need to think independently has not decreased as Memmi ages, but increased given the uncertainties of the contemporary world which remains, in his view, full of illusions and stupidity. As long as religion takes advantage of these uncertainties, as do nationalism and hatred of the other, and while the media acts irresponsibly, old, discredited ideas return. Memmi opens the Dictionnnaire critique by explaining that the aim is to test some of the ideas that help him think, and in so doing he shows how those he takes as his targets may purport to "think", to promote and defend a belief system of one kind or another, but they care little for truth and their "thought" only serves to reinforce their own ideas and that of the group to which they belong. ${ }^{34}$ Indeed, to think openly and honestly, one has to be a "heretic". 35 The thinker should respect nothing and no-one, except truth - to which I will return - and the road to truth is a long and difficult one. ${ }^{36}$ Indeed, one way to think for oneself is to write one's own Dictionary, as Memmi advises us to do, just as he as, in order to navigate the times in which one lives.

\section{Two: Being Means Being Different}

Memmi's own identity wounds may have healed, but the scars remain even as an old man, and those scars are the consequences of his original battles with the issues of being Jewish, North African, of poor origins:

Je m'empresse d'ajouter que cette angoisse, si elle n'est pas totalement apprivoisée, me procure le sentiment d'une victoire relative sur le sort et sur moi-même. Lors de la parution de mon premier livre, qui déjà fut un inventaire, on en a quelquefois cité cette phrase: "Indigène dans un pays de colonisation, juif dans un univers antisémite, Africain dans un monde où triomphe l'Europe..." Il n'y avait pas que cela dans l'ouvrage, mais ce passage en résumait l'un des aspects principaux. Or le temps a passé. Je suis maintenant de nationalité française, même si je n'ai pas renié ma citoyenneté d'origine et si demeurent en moi des fidélités tenaces. Le racisme est partout stigmatisé, même s'il n'est pas toujours commode d'être juif. Il n'est plus si infamant d'être d'origine africaine, même si persiste le malheur d'Afrique. Quant à la pauvreté, n'ayant guère de goûts dispendieux, une honnête carrière universitaire a suffi à mes besoins. Bref, mes blessures se sont renfermées, même si les cicatrices sont là, bourrelets 
gênants qui se rappellent de temps en temps à mon attention. $^{37}$

(I hasten to add that this anguish, although not totally subdued, also provides me with a sense of relative victory over fate and over myself. When my first book, which was already a stock-taking, appeared, there was a passage which was often quoted: 'Native of a colonized country, Jewish in an anti-Semitic universe, African in a world where Europe was triumphing...' There was not only that in the book, but that passage summed up one of its main aspects. Now time has gone by. I now have French nationality, though I have not renounced my original nationality and fiercely retain old loyalties. Racism is condemned everywhere, though it is still not always comfortable to be Jewish. It is no longer so shameful to come from Africa, though Africa's wretchedness still persists. As for poverty, never having had expensive tastes, an honest university career has sufficed for my needs. In short, my wounds have healed, even though the scars are there, painful patches which remind me of their existence from time to time.)

For Memmi, the experience of poverty and the internal conflict caused by the awareness of being poor brought about the development of a political awareness. Poverty is, for him, a form of oppression that must always be seen in relation to wealth, another form of dominating and being dominated which forms such an important part of Memmi's critical and sociological thinking: "En somme, oui, je fais de la pauvreté une variété de l'oppression [...] La pauvreté est relative à la richesse, qui l'entretient dans l'obsession de sa misère." (Altogether, yes, I count poverty as a type of oppression [...] Poverty is relative to wealth, which keeps it obsessed with its own wretchedness). ${ }^{38}$ It is, however, above all his Jewish identity that had an impact on Memmi's thinking and on his conduct, and he insists on the inescapable fact of difference - noting especially a certain hypocrisy in how his thinking on Jewish identity has been received:

Contre ceux qui ne voulaient pas reconnaître la spécificité de la condition juive - qui, après m'avoir applaudi lorsque je dénonçais la condition des colonisés, me suspectaient d'un attachement réactionnaire à la judéité, et, plus généralement, me reprochaient de donner trop d'importance à la notion de la différence, prêtant ainsi flanc à l'agression raciste, et rendant l'intégration plus difficile, étc. [...] j'ai écrit: "Etre, c'est être différent." Je continue à le penser, parce que ce n'est pas une revendication mais l'énoncé d'un constat: on n'existe pas 
comme un être abstrait, mais comme individu singulier, avec des caractéristiques et des attaches particulières [...] La différence est un fait; je n'en fais pas pour cela un drapeau, ni une arme. Il n'y a pas de quoi en être fier, ni s'en affliger. Elle ne légitime en rien une surenchère de soi. $^{39}$

(Against those who did not wish to recognize what is particular about being Jewish - who, after applauding me when I denounced the conditions of the colonised people, then suspected me of a reactionary attachment to Jewishness and, more generally, reproached me for according too much importance to the notion of difference and thus opening up a front to racist aggression, making integration more difficult, etc. [...] I wrote, 'Being means being different.' I still think so, because it is not a claim but a statement of an observed fact: one does not exist as an abstract being but as a specific individual, with particular characteristics and attachments. [...] Difference is a fact; which doesn't mean I make it into a flag or a weapon. It's not something to be proud of or to get upset about either. It does not justify over-valuing oneself.)

If "being means being different," the challenge, as Memmi says, is to reconcile our individual differences. Memmi has himself inhabited a space that is "in between" (his own image, used for the title of a chapter in Le Nomade immobile, is being on a pont suspendu, a suspension bridge) as he has engaged in the struggle to remain in solidarity with the community from which he came, while being critical of it when necessary within a wider analysis of the effects of colonialism on the identity of the individual and of the community, and more widely on power relations in human relationships and behavior. As he writes in Testament insolent, the ideal state is: "ne pas nier son appartenance, ne pas refuser sa solidarité, mais ne pas céder aux mythes des siens: à l'occasion, si nécessaire, on doit en dénoncer les dérives et les excès" (not to deny one's belonging, not to refuse one's solidarity, but not to give in to the myths of one's people: on occasion, if necessary, one must denounce their derivations and excesses). ${ }^{40}$ The individual's relationship and their belonging to the group of origin are not to be denied (as above), belonging being defined as: "le sentiment, plus ou moins accepté, que l'on a des liens indéfectibles avec son groupe d'origine; ce qui entraîne une solidarité spontanée et des devoirs envers lui" (the feeling, accepted to a greater or lesser extent, that one has of the enduring links to one's group of origin; which entails spontaneous solidarity and duties towards it) ${ }^{41}$, but sometimes in order to "distinguish between myth and reality," those ties of belonging need to be loosened: "sans la renier, il faut se refuser à se laisser caractériser uniquement par son identité culturelle" (without rejecting it, one must refuse 
to let oneself be defined by one's cultural identity alone) ${ }^{42}$, and in order to do that the elements that define that group must be questioned and, if necessary, criticized.

\section{Three: Denounce All Impostors}

Memmi's thinking is very much of a piece, and one position runs on from another. If one intention is, then, to free the individual from a total identification with a group and its values, then it follows that all forms of systemized and institutionalized thinking are to be questioned. What I am terming "imposters" here are many and varied - and variously called "fictions", "illusions", "hallucinations" by Memmi -, but all share one characteristic: they are collective doctrines of one type or another which profess to know the truth about human existence while concealing their real nature, and all prevent the individual from thinking for him or herself, thereby contravening Lesson One above. Religion is clearly the greatest imposter of them all, and no organized religion or religious interpretation emerges unscathed since all ultimately privilege the "divine" over the human and another type of "life" at the expense of this one: "Le moins qu' on puisse dire enfin est que le christianisme n'est pas un humanisme, car il fait abstraction de la réalité de l'homme vivant" (The least one could say, finally, is that Christianity is not a form of humanism, because it makes an abstraction of the reality of the living human being). ${ }^{43}$ Religion is a form of dependence, this time on something imaginary, a supposedly supernatural being, and is fabricated according to a set of myths, not according to a moral doctrine: " $c$ 'est la mythologie qui fait l'essentiel des religions, non la morale comme on feint de croire aujourd'hui, pour obéir à l'air du temps" (it is mythology which makes up the essential part of religions, not morality as people pretend to believe today, in deference to the prevailing atmosphere). 44 His greatest criticism is that religion prevents logical thinking, and theology takes for its object a representation that is treated as though it were a reality. Faith is based on an absolute conviction that has not been subjected to any proper experiment or testing, and for Memmi the irrational can never supersede the rational: "La religion est la littérature devenue folle: elle pretend que ses fables sont véridiques, les plus fantaisistes y compris" (Religion is literature gone mad: it pretends that its fables are true, even the most fantastical ones). ${ }^{45}$ Memmi's greatest tool in his method here is to pursue a rational line of thought applied to the belief system in question which ends by showing the untenable and sometimes ridiculous position it upholds. ${ }^{46} \mathrm{He}$ demonstrates this to its logical, ludicrous end in the Dictionnaire critique while discussing the major world religions' arguments over Jerusalem, "la gare obligée pour tout départ vers le ciel," (the obligatory station for every departure to heaven), and their need to practice the art of the exclusion of the non-righteous both within and outside their own religion: "Or, ici surgit un nouveau problème: chacun prétendant en posséder les clefs exclusives, comment les autres pourraient-ils y entrer?" 
(Now, here a new problem arises: since each claims to possess the keys exclusively, how could the others enter?). ${ }^{47}$ Worse, those who are not believers accept that others do have religious faith, but the same tolerance is not reciprocated, indeed the lack of tolerance is one of the worst characteristics of religion, 48 and those who adhere to a religion appear unaware of where their belief system leads if taken to its logical end: "Mais on est toujours puni par où l'on a péché: cet exclusivisme, interne et externe, avoué ou voilé, se transforme en piège. Excluant tous les autres, chacun s'exclut du reste de l'humanité" (but one is always punished on the point where one has sinned: that exclusivism, internal and external, overt or covert, becomes a trap. In excluding all the others, each excludes himself from the rest of humanity). ${ }^{49}$ Religion and political doctrines - notably Marxism as practised and preached by "followers" of Marx, not Marx himself - are obvious targets, as are other doctrines such as psychoanalysis (again as practiced by the "anemic" descendants of Freud, not by Freud himself) and all rigid systems of thinking that exclude those who do not conform and whose goal may ostensibly be to defend the individual, but which in reality serve only to preserve the group and its belief system. Memmi also urges wariness of less obvious things - art and culture, for example, not as entities themselves, but because of the types of discourses often "sacralizing" discourses - which distort them: "Il faut déscraliser la culture" is a chapter title both in Le Nomade immobile and in Testamant insolent, and if Memmi can write that religion is literature gone mad, then it follows that literature is a kind of religion. Why? Once again, because of the recourse to the imaginary: "l'art, comme la religion, comme la magie, est une tentative de maîtriser le réel par l'imagination" (art, like religion, like magic, is an attempt to master what is real by imagination), 50 even if the imagination, as he fully recognises, has also helped us to survive: "Dans le projet, il y a de l'imaginaire" (in the project there is also imagination). 51 When Memmi's personal cultural tastes are displayed, he is much less successful in his argument (his dismissal of some of Marguerite Duras's work and of the French New Novel add nothing to his discussion and even undermine it), but the logic of his thought as a whole remains. Reason must always hold sway over the imagination: "En somme, sans mésestimer les données de l'imaginaire, il faut toujours privilégier les conseils de la raison... si l'on y arrive" (All in all, without underestimating the gifts of imagination, it is always necessary to give priority to the counsels of reason... if one can). ${ }^{52}$ Distrust emotion and cultivate reason seems to be the maxim; writing about contemporary conflicts (and of the ways in which they are reported in the media), he warns: "l'émotion ne peut remplacer une analyse sérieuse et globale d'un conflit [...] Nous découvrons là, une fois de plus, le rôle de l'imaginaire dans la conduite et la pensée des humains, et qu'il faudrait tâcher de le réduire" (emotion cannot replace a serious global analysis of a conflict [...] We discover there, once again, the role of the imagination in human behavior and thought, and that one ought to try to reduce it). ${ }^{53}$ 
Emotion is certainly legitimate, and he does recognize the importance of emotion in art, but it does not replace rigorous thought - any lack of rationality in thought and behavior is attacked by Memmi.

\section{Four: Be a Humanist}

It therefore follows logically that the human should be the centre of our concerns and that above all, we must refuse to sacrifice humankind to any and all myths. ${ }^{54}$ The greatest criticism leveled at religion by Memmi is that it finally denigrates the value of the human. When he writes of his aims of "l'esquisse d'une philosophie" (the outline of a philosophy) at the beginning of the Dictionnaire critique, he makes explicit the intent: "disons qu'il s'agit en gros de montrer que l'homme prime sur le mythes et même sur les idées et les groupes" (let's say that it is overall a matter of showing that humankind takes precedence over myths and even over ideas and groups). ${ }^{55}$ This adherence to the belief of giving primacy to human endeavor and survival, can lead to nuanced thinking by Memmi. While "culture" is considered a collective act in his own definition: "la culture est l'ensemble, changeant, et plus ou moins cohérent, des réponses d'une collectivité à ses conditions d'existence," (culture is the totality, changeable, and consistent to a greater or lesser degree, of the responses of a collectivity to its conditions of existence), and may simply serve as a convenient and reassuring refuge from our fears concerning suffering, old age and death, because culture is something specific to humankind and is indeed unique to the human, it escapes the criticism directed at other forms of collective thinking:

[...] elle fonde la personnalité collective, où s'enracine et s'abreuve continûment la personnalité individuelle ; elle inspire les sentiments d'appartenance. A cet égard, je ne partage que partiellement les conceptions qui considèrent la culture comme une contrainte. Certes, elle est contrariante pour le désir individuel, afin de permettre la vie collective, mais, en même temps, elle offre à l'individu des recours précieux. Les contraintes inventées par le groupe deviennent en retour des moyens de se libérer des contraintes naturelles, et même, paradoxalement, de se libérer du groupe. ${ }^{56}$

([culture] is the basis for collective personality, in which the individual personality is rooted and constantly draws nourishment; it inspires feelings of belonging. In this regard, I only partly share the conceptions that consider culture as a constraint. Admittedly, it restricts individual desires in order to make collective life possible, but at the same time it offers priceless resources to the individual. The constraints invented by the group become in return a means of freeing oneself from the constraints of nature, 
and even, paradoxically, of freeing oneself from the group.)

Humanism should be the guiding principle of philosophy, and is the centrepiece of Memmi's thinking: "A quoi sert la connaissance sinon, pardelà le plaisir de la curiosité, à maîtriser le réel à notre profit? La morale, sinon à régler notre conduite en vue d'une meilleure vie commune? A quoi sert la métaphysique, dont la religion est l'une des expressions, sinon mieux nous situer dans l'univers ?" (What use is knowledge if not, beyond the pleasure of curiosity, to master reality for our benefit? What use is morality, if not to regulate our behavior in favor of a better communal life? What use is metaphysics, of which religion is an expression, if not to situate ourselves better in the universe?). ${ }^{57}$ We are currently, in Memmi's view, witnessing an extraordinary offensive against humanism, and it should not surprise us that a philosophy which places humankind at its centre should be attacked by any system that serves groups and ideologies. In one of his most unequivocal statements, Memmi proclaims the primacy of the human: "l'homme doit être le centre, le critère et le but de la connaissance et de l'action [...] c'est la seule philosophie qui défende l'homme contre toutes les idolâtries, religieuses, financières ou politiques, et même contre l'homme luimême" (humankind should be the center, the criterion and the goal of knowledge and action [...] it is the only philosophy that defends humankind against all idolatries, religious, financial or political, and even against humankind himself). ${ }^{58}$ Only humanism can resist the return of extremism in politics and religion as we are currently witnessing them. Allied to the importance of humanism is that of holding to non-religious principles - lay principles - and "laïcité", so fundamental to the French Republic and which becomes in Memmi term "laïcisme", is currently subjected to an onslaught from religious believers of all kinds:

Alors que le laïcisme est la seule philosophie qui, socialement, n'exclut personne, qui respecte les différences et les droits de chacun... sauf celui d'exclure les autres [...] $C^{\prime}$ est une philosophe où tout se discute, se négocie, même les limites de la liberté, y compris peut-être la liberté de s'exprimer. Car c'est l'homme qui est la mesure de tout, la fin dernière de la sagesse, non les dieux ou même la liberté : le laïcisme est très généralement un humanisme.59

(While laicism is the only philosophy which, socially, excludes no-one, which respects each person's rights and differences... except that of excluding others [...] It is a philosophy where everything is subject to discussion, is negotiable, even the limits of freedom, including perhaps freedom of expression. Because it is man who is the measure of all things, the last end of wisdom, not gods or even freedom: laicism is very generally a humanism.) 
In terms of establishing a moral code, again humankind must be at its centre, and in this Memmi still follows and approves Nietzsche: "En bref l'homme à la place des idoles. Si ce n'est là une morale, qu'est-ce que la morale? Le nietzschéisme est une tentative originale de rétablissement de l'homme dans son intégrité et dans sa dignité" (In short, humankind in the place of idols. If that is not a morality, what is? Nietzschism is an original attempt to reestablish man in his integrity and in his dignity). ${ }^{60}$ Quite simply, for Memmi, the most terrible things that a human being does, are when $\mathrm{s} /$ he ceases to consider humankind as central to life.

\section{Five: Love and Enjoy Life}

A life in which one is constantly on guard against the delusions of the emotional and the irrational might seem austere, but Memmi's life lessons do not preclude the enjoyment of life, of friends and family, of love, far from it. Indeed one reason for retracing his thinking and his life journey, his "testament", is to procure pleasure for himself. However, Memmi's views on what constitutes a good and happy life are more difficult for a generalized life lesson given that he unashamedly celebrates living in a heterosexual couple and having children. He is aware of this: "Je crains de n'être pas au goût du jour en reliant ainsi la sexualité à la procréation" (I fear I am not to today's taste in linking sexuality to procreation in this way), ${ }^{61}$ but he remains adamant in his view, remaining faithful to his method of thinking: "Nous voilà encore dans un débat interminable : faut-il renoncer à la vérité pour ne pas risquer de passer pour rétrograde" (Here we are again in a never-ending debate: should one renounce truth so as not to risk seeming retrograde). ${ }^{62}$ Certainly it is difficult for a reader from another generation, gender and cultural area not to find this the area of Memmi's greatest selfjustification. His claim in these pages that he has defended equality and justice for women to such an extent in his work that no-one could question his attitude towards women, and that the proof of how much he loves women and how important they are in life precludes any charges of misogyny, really does resonate with the defensiveness of someone who protests too much. The life lesson might be then: "live in a heterosexual couple and have children," but that would allow these uncomfortable aspects of his expression to blind us to his more interesting reflections on love and life, not least since he identifies it as the part of our lives where the imaginary is so important and therefore requires very subtle thinking on his part given his mistrust of the imaginary in other areas of human conduct and thinking:

Soit la conduite amoureuse, où la dimension imaginaire est particulièrement notable [...] Même la religion, l'art n'ont pas la même importance. Nous pouvons être croyants ou non croyants, passionés de l'art ou indifférents, nous sommes tous confrontés à la 
dépendance érotique. On trouve tout dans ce plus merveilleux des duos, la sexualité, la tendresse, l'émotion [...] De sorte que, si nous voulons nous comprendre, il nous faut faire l'inventaire de cette relation, imaginaire compris. 63

(It is behavior in love, where the dimension of the imagination is particularly noticeable [...] Even religion, art, don't have the same importance. Whether we are believers or non-believers, passionate about art or indifferent, we are all confronted with erotic dependence. One finds everything in this most marvellous of "duos", sexuality, tenderness, emotion [...] So that if we want to understand ourselves, we need to take stock of this relationship, including the imagination.)

In fairness, he does not condemn homosexuality - this would fly in the face of his defense of tolerance - but it poses a problem for his view of human relationships, as does sexual abstinence. Nonetheless, the celebration of an appetite for life and its joys is full of energy, and is a life lesson for living well. It is not surprising that Testament insolent ends with "Le bien vivre" (living well) in which he finally wonders if the search for happiness is not perhaps the final word; or that Memmi spent a year writing for Le Monde on "Happiness", including those small moments of happiness which are the only ones that can be certain in our lives: "sagesse, bonheur et sérénité vont ensemble" (wisdom, happiness and serenity go together). In the epilogue to Le Nomade immobile, he writes: "Le bonheur est devenu pour moi une évidence et une nécessité" (happiness has become for me something obvious and a need). ${ }^{64}$ In one of his most succinct positions, Memmi sums it up: "La question 'à quoi sert de vivre?' est encore une fausse question, elle sousentend que l'on doive vivre pour autre chose que la vie" (The question 'What use is living?' is still a false question, implying that one ought to live for something else than for life), bringing him close once again to Montaigne's "Life should be an aim unto itself, a purpose within itself" in his final essay. ${ }^{65}$ Life is an end in itself, but living well requires an effort; it is more than a matter of constantly choosing what one should and should not do, and in a seemingly contradictory final position, Memmi insists that in order to understand human beings properly, we must understand the imaginary since it is an integral part of us. In the end, it is the irrational - not the imagination - that is the greatest enemy to living well and to allowing others to do the same. ${ }^{66}$

\section{Six: Seek Out Truth(s)}

Truth and pleasure, then, are not so far apart. Memmi is repulsed by any dogma which professes to possess "Truth." This is because the rigid beliefs of adherents to any dogma result in a position in which they: 
"s'interdisent et interdisent aux autres de chercher les modestes vérités qui nous sont accessibles" (forbid themselves and forbid others to seek the modest truths that are accessible to us), when his own relationship to truth is very different: "Je trouve au contraire de la jouissance quand je crois avoir aperçu quelque rapport inédit dans le réel, fût-il minime, et le partage avec mes lecteurs" (On the contrary, I rejoice when I believe I have found some unknown connection in reality, however small, and I share it with my readers). ${ }^{67}$ The search for truth is Memmi's most fundamental principle and is what has driven his thinking forward from his days as a young student of philosophy to the writings of his old age. He writes in his Dictionnaire critique that truth is aligned with experience, and that "experience" is "la reine des savoirs" (the queen of all the branches of knowledge): "Seule l'expérience l' [le vrai] établit, progressivement et statistiquement. La route vers la vérité est longue et sinueuse, parsemée de nécessaires vérifications répétées" (Only experience establishes [the truth] progressively and statistically. The road to truth is long and winding, sown with necessarily repeated verifications). ${ }^{68}$ The quest for truth lies at the heart of his life project and of his writing project and is integral to the way he has lived his life, even though he remains troubled by this duty and about how he should, or indeed whether he should, share his conclusions with others:

Le goût de la vérité est double: besoin de rechercher la vérité, besoin de la faire partager. Si penser juste me paraît toujours une obligation envers moi-même, je suis moins sûr de devoir l'exiger des autres, ni même de faire partager mes conclusions. Pourquoi s'échiner à révéler ce que l'on croit être vrai à des gens qui ne souhaitent pas vous entendre? Pour se rassurer soi-même? Pour vérifier ce que l'on croit avoir découvert? Ou, et c'est plus suspect, pour imposer ses vues et jouir de ce pouvoir? Peut-on et doit-on tout dire? Qui nous le demande vraiment? Horreur! Suis-je loin des prosélytes que je dénonce? Je suis pris par la tentation du masque, et comprenne qui pourra. ${ }^{69}$

(The taste for truth is double: the need to seek it out, and the need to share it. But although thinking rightly always seems to me a duty I owe myself, I am less sure that I ought to demand it of others, or even share my conclusions with others. Why wear yourself out trying to explain what you believe to be true, to people who don't want to understand you? To reassure yourself? To verify what you think you have discovered? Or - and this is more suspect - to impose your views on others and enjoy the sense of power? Can we and should we say everything? Who honestly demands this of us? Horrors! 
Am I, after all, so far from the proselytes I denounce? And then I am seized by the temptation to mask myself, and let anyone understand me who can.)

Yet, almost ten years later than this hesitation in Le Nomade Immobile, he is indeed still explaining, still denouncing irrational thinking, still adding a post scriptum in case he has not been clear enough, and "Le goût et la recherche de la vérité" (the taste and the search for truth) is the penultimate chapter title of Testamant insolent: "la recherche de la vérité est l'une des principales conditions de la sagesse" (the search for truth is one of the main conditions of wisdom). ${ }^{70}$ Choosing between "philosophy" and "wisdom", he finds his own definition: "bien conduire sa pensée afin de bien conduire sa vie" (conducting one's thoughts properly in order to conduct one's life properly); ${ }^{71}$ and this is the underlying principle for the life lessons above since in the end his understanding of philosophy is: "simplement la meilleure manière de vivre et la recherché des moyens d'y parvenir" (simply the best way of living and the search for the means to achieve it). ${ }^{72}$

\section{And Finally, Write it Down: "une seule intention complexe"}

To conclude, I will briefly return to Memmi's most complex and on many levels most intriguing narrative, Le Scorpion (The Scorpion, or the imaginary confession), published in 1969. This most complex piece of literature is evoked here in this final section as a reminder of the power of the younger Memmi's writing, but also to show how much of "one piece" Memmi's work is. At one point in Marcel's commentary on Emile's mysterious textual enterprise, he thinks that he is beginning to understand the method in the apparent madness:

[...] à moins que ces différents textes ne soient pas tout de même indépendants. Je veux dire qu'ils soient déjà destinés, sitôt jetés sur le papier, à entrer dans un dessein unique, plus général [...] Hypothèse farfelue, et surtout embarrassante; car, alors, il n'y aurait ni fiction, ni Journal, ni document, mais une seule intention complexe. Ce serait pire ; comment ordonner ces feuilles, sans connaîre cette intention, sans moyen de se retrouver à l'intérieur même de ces textes? ${ }^{73}$

([...] unless all these different pieces are not really independent. By that I mean that they were already intended, as they were put down on paper, to be part of one overall plan. [...] It's a crazy idea, and an awkward one too, because in that case, there'd be neither fiction nor Journal nor document but instead, one complex intention. That would be worse. How can I put these pages in order 
without knowing what his intention was, without a way of moving right inside what he's written?)

"One complex intention" could be a summary of the whole of Memmi's project; and if we are unable or unwilling to "move right inside" what he has written, and if we do not look inside ourselves as we read, we are not fulfilling the role of the reader of Memmi's work. In Le Scorpion, Memmi seemed to be preoccupied with the status of his whole enterprise to date (and prophetically, his work in the future) - literary, sociological, personal, political - and its possible value. On the one hand literature is a "healthy" endeavor, on the other it is futile, merely decorative; his socio-political work reveals the mechanisms of human power relations, but does not change anything in the real political system. The writer's work is at once necessary and meaningless. His analyses have helped him and others to understand better their place in the world, but he is unsure that any real changes have been made. Memmi has written that his whole life has been a battle: a battle to be a writer, to master a language, and finally to become a philosopher yet another attempt to master the world. ${ }^{74}$ Philosophy is for him above all: "une sagesse fondée sur les savoirs: l'art de conduire sa vie le plus raisonnablement possible" (a wisdom founded on the branches of knowledge: the art of conducting one's life as reasonably as possible). ${ }^{75} \mathrm{He}$ attempts to remain constantly on guard against pride and self-obsession, conscious that he has built a whole body of work on his own experience. Much of his work is, indeed, a self-examination in the French philosophical tradition that begins with Descartes and Montaigne and which echoes throughout literature and philosophy in France thereafter. He does not always succeed in his vigilance, and some of the tenets and explanations in these later texts become repetitive and sometimes self-justifying as has been discussed, some of his personal tastes sit uneasily with the claim to the universal based on individual experience. Yet, he tries and that is perhaps another final life lesson: he tries to be clear, he tries to think more and to think harder. In the epilogue to Le Nomade immobile, Memmi gives a description of his personal working environment and of two images which resonate with the concerns of Le Scorpion: the redemptive nature of confession and the narcissistic nature of writing. ${ }^{76}$ At the end of such a life project, is the writer/philosopher finally able to find satisfaction in his life? Memmi seems to suggest that the former poor Jew, former colonized subject, uneasy intellectual, part of a minority all his life, has come to an acceptance of all the facets of his identity, even though this state remains tentative and seems more like a truce than a reconciliation. In texts written decades after Le Scorpion, he remains angry at, and scathing of, all doctrines and their posturing, and of lazy thought that does not pursue a rational agenda. The problems of identity, of belonging and not belonging, of exile and of finding a place in the world appear to find some resolution - indeed some kind of salvation - in the act of writing. Writing for Memmi is an act that is at once necessary and potentially meaningless, hence the necessity of the writer to 
adopt an ethical position towards the creative process so that it becomes a testimony to a way of living, that way of being in the world which was evoked earlier. Writing then becomes a very necessary intervention. Memmi himself tries to define "cette leçon d'une vie" which his life represents:

C'est une tentative pour découvrir dans le réel [...] une triple ou une quadruple cohérence relative : une coherence éventuelle entre nos savoirs, si possible une cohérence entre nos conduites, les deux liées dans une troisième cohérence, entre nos savoirs avérés et nos conduites, ce qui devrait nous mener à une certaine sagesse. En somme, $j^{\prime}$ en attends surtout qu'elle m'aide à vivre au mieux. ${ }^{77}$

(It is an attempt to discover in reality [...] a triple or quadruple relative coherence: a possible coherence between our branches of knowledge, if possible a coherence between our behaviors, both linked in a third coherence, between our certain knowledge and our behavior, which ought to lead us to a certain wisdom. To sum up, I expect above all that it will help me to live as well as possible.)

There is then, nothing new to be invented to arrive at wisdom about ourselves, we use knowledge that we already possess, but that we have perhaps not applied as fully as we could. Perhaps this is why ageing and death do not feature as full meditations in Memmi's late texts, despite his own great age. The lesson of a life is an attempt to apply knowledge gained; and it is the attempt then that is most essential, for in the end anyway, as Memmi reminds us, philosophy is simply a way of seeing the world, it is itself an opinion, and nothing more, but the experience is everything. ${ }^{78}$ How to live?:

Ai-je appris à vivre, enfin ? [...] A l'instar de ces gens qui font graver sur leur tombe ce qui leur paraît leur principale mérite, je souhaite qu'on mette sur la mienne: “il a tenté d'être sage et réussi quelquefois à être heureux. "79

(Have I learnt how to live, finally? [...] Following the example of those people who want to have engraved on their tombs what they feel to be their principle merit, I hope that there will be engraved on mine: 'He tried to be wise and sometimes succeeded in being happy.') 
1 Albert Memmi, Le Nomade immobile (Paris: Arléa, 2000), 199. I am thankful to Helena Scott who has prepared all the translations of Memmi's work included here.

${ }^{2}$ This is a reference to Memmi in Le Nomade immobile: "Chacun de mes livres aura été une étape d'un même itinéraire" (10).

${ }^{3}$ For his work on racism, see also the book length essay Le Racisme: Description, définition, traitement (Paris: Gallimard, 1982, 1994) in which he also develops his concept of heterophobia. On dependency, see La Dépendance: Esquisse pour un portrait du dépendant (Paris: Gallimard, 1979, 1993) and Le Buveur et l'Amoureux: Le prix de la dépendance (Paris: Arléa, 1999).

${ }^{4}$ This continues to be a theme of the critical discourse on Memmi's work; see for example Afifa and Samir Marzouki, Individu et communautés dans l'œuvre littéraire d'Albert Memmi (Paris: L’Harmattan, 2010).

5 Joëlle Strike, Albert Memmi: Autobiographie et autographie (Paris: L'Harmattan, 2003), 209, 213. She notes, for example, the similarities between A Contre-courants (Paris: Nouvel Objet, 1993) and Feu sur 40 idées reçues (Paris: Corlet, 1999), the first more "austere" than the second apparently (re)written and (re)published and aimed at a wider public.

${ }^{6}$ Oliver Davis, Age Rage and Going Gently: Stories of the Senescent Subject in Twentieth-Century French Writing (Amsterdam and New York: Rodopi, 2006), 18.

${ }^{7}$ Erik Erikson, Childhood and Society (New York: Norton, 1950) and The Life Cycle Completed: A Review (New York: Norton, 1982). Oliver Davis describes Erikson's psychosocial and psychosexual scheme as: "remarkably prescriptive, socially conservative and [...] narrowly heterosexual" (Davis, Age Rage, 131). Adulthood is characterized as "generativity vs. stagnation". This chimes very well with Memmi's celebration of the heterosexual couple as will be discussed.

${ }^{8}$ Memmi, Nomade immobile, 109.

${ }^{9}$ A reference to the chapter entitled "La philosophie, bien penser pour bien agir" in Le Nomade immobile, 208-220. 
${ }^{10}$ Memmi, Nomade immobile, 211.

11 Albert Memmi, Dictionnaire Critique à l'usage des incrédules (Paris: Le Félin, 2002), 11. We do not propose here to present a detailed analysis of the republishing, under different titles and in different styles for different publics, of Memmi's work that has appeared previously, although this is a clear example of a re-packaging of the earlier text $A$ Contre-courants (see, for example, the explanation of the aims of the two works which are extremely similar).

${ }^{12}$ Memmi, Dictionnaire critique, 10.

${ }^{13}$ For a more detailed reading of Memmi's work as a "project", see the chapter "Albert Memmi: Fictions of Identity and the Quest for Truth" in Debra Kelly, Autobiography and Independence: Selfhood and Creativity in North African Postcolonial Writing in French (Liverpool: Liverpool University Press, 2005), 131204.

${ }^{14}$ See Guy Dugas, Albert Memmi, écrivain de la déchirure (Sherbrooke: Naaman, 1984), 31.

${ }^{15}$ Albert Memmi, Testament insolent (Paris: Odile Jacob, 2009), 34. Italics in the original.

${ }^{16}$ Memmi, Testament insolent, 67.

${ }^{17}$ Memmi, Testament insolent, 68. Italics in the original.

${ }^{18}$ Memmi, Testament insolent, 80-81.

${ }^{19}$ Dugas, Albert Memmi, 28.

${ }^{20}$ Albert Memmi, “Autoportrait," Souffles 6 (1967): 9.

${ }^{21}$ Memmi, Le Nomade immobile, 109.

${ }^{22}$ Memmi, Nomade immobile, 10.

${ }^{23}$ Memmi, Testament insolent, 12. Italics in the original. 
${ }^{24}$ Even though he kept his distance from Sartre and the Parisian intellectuals around him at the time.

${ }^{25}$ Memmi, Nomade immobile, 149-152.

${ }^{26}$ Sarah Bakewell, How to Live: A Life of Montaigne in one question and twenty attempts at an answer (London: Chatto \& Windus, 2010).

${ }^{27}$ Bakewell, How to Live, 4.

${ }^{28}$ Memmi, Testament insolent, 20.

${ }^{29}$ Memmi, Nomade immobile, 188-189.

${ }^{30}$ Memmi, Nomade immobile, 48-50.

${ }^{31}$ Memmi, Nomade immobile, 47.

${ }^{32}$ Memmi, Nomade immobile, 25-26.

${ }^{33}$ Memmi, Testament insolent, 198.

${ }^{34}$ Memmi, Dictionnaire critique, 19-20.

${ }^{35}$ Memmi, Dictionnaire critique, 38.

${ }^{36}$ Memmi, Testament insolent, 226; Dictionnaire critique, 99.

${ }^{37}$ Memmi, Nomade immobile, 55.

${ }^{38}$ Albert Memmi, Ce que je crois (Paris: Grasset, 1985), 58.

${ }^{39}$ Memmi, Nomade immobile, 130-131.

${ }^{40}$ Memmi, Testament insolent, 93.

${ }^{41}$ Memmi, Testament insolent, 90. Italics in original.

${ }^{42}$ Memmi, Testament insolent, 94. 
${ }^{43}$ Memmi, Dictionnaire critique, 312.

${ }^{44}$ Memmi, Testament insolent, 139.

${ }^{45}$ Memmi, Dictionnaire critique, 40.

${ }^{46}$ Memmi, Testament insolent, 148-152. There is a sustained use of humor and irony in Memmi's work that has been largely overlooked.

${ }^{47}$ Memmi, Dictionnaire critique, 80.

${ }^{48}$ Memmi, Testament insolent, 160.

${ }^{49}$ Memmi, Dictionnaire critique, 83.

${ }^{50}$ Memmi, Testament insolent, 169. Italics in original.

${ }^{51}$ Memmi, Testament insolent, 169.

${ }^{52}$ Memmi, Testament insolent, 103.

${ }^{53}$ Memmi, Testament insolent, 99.

${ }^{54}$ Memmi, Testament insolent, 101.

${ }^{55}$ Memmi, Dictionnaire critique, 11.

${ }^{56}$ Memmi, Dictionnaire critique, 57; 59-60.

${ }^{57}$ Memmi, Dictionnaire critique, 147.

${ }^{58}$ Memni, Dictionnaire critique, 150-151.

59 Memmi, Dictionnaire critique, 194-195. This is an article that originally appeared in Le Monde, $29^{\text {th }}$ May, 1989 during the aftermath of the Rushdie Affair. The postscriptum serves to underline Memmi's commitment to the term "laïcisme" rather than the usual "laïcité." 
${ }^{60}$ Memmi, Dictionnaire critique, 243.

${ }^{61}$ Memmi, Testament insolent, 106.

${ }^{62}$ Memmi, Testament insolent, 107.

${ }^{63}$ Memmi, Testament insolent, 104-105.

${ }^{64}$ Memmi, Testament insolent, 250; Nomade immobile, 274; and see also Bonheurs (Paris: Arléa, 1992, 1998); Ah! quel bonheur (Paris: Arléa, 1995, 1999) ; L’Exercice du bonheur (Paris: Arléa, 1998).

${ }^{65}$ Memmi, Dictionnaire critique, 234.

${ }^{66}$ Memmi, Testament insolent, 249.

${ }^{67}$ Memmi, Testament insolent, 24.

${ }^{68}$ Memmi, Dictionnaire critique, 99.

${ }^{69}$ Memmi, Nomade immobile, 52.

${ }^{70}$ Memmi, Testament insolent, 207.

${ }^{71}$ Memmi, Testament insolent, 208.

${ }^{72}$ Memmi, Testament insolent, 250.

${ }^{73}$ Albert Memmi, Le Scorpion (Paris: Gallimard, 1969), 44. Italics mine.

${ }^{74}$ Memmi, Nomade immobile, 25.

${ }^{75}$ Memmi, Nomade immobile, 25.

${ }^{76}$ Memmi, Nomade immobile, 267

${ }^{77}$ Memmi, Testament insolent, 17.

${ }^{78}$ Memmi, Testament insolent, 19. 
${ }^{79}$ Memmi, Nomade immobile, 277-278. 